\title{
Heterogeneity of Fc Receptor Expression in Chemotaxis and Adherence of Neonatal Neutrophils
}

\author{
KIYOKAZU MASUDA, YO KINOSHITA, AND YOHNOSUKE KOBAYASHI \\ Department of Pediatrics, Kansai Medical University, Osaka 570, Japan
}

\begin{abstract}
Chemotaxis and adherence to polymorphonuclear neutrophils (PMN) subpopulations from cord blood of 13 healthy neonates and blood of 16 healthy adults as control subjects were determined using the rosetteforming procedure, the modified Boyden method, and ${ }^{51} \mathrm{Cr}$ adherence assay. The percentage of rosette-forming neutrophils (RFN) (Fc receptor expression) of cord PMN (35 $\pm 8 \%$ ) was significantly lower than that of adult PMN (60 $\pm 4 \%, p<0.01$ ). Differences in chemotaxis of PMN subpopulations between cord and adult PMN after stimulation by their own endotoxin-activated plasma were as follows: (i) unfractionated adult PMN (A) $(n=10)$ versus adult RFN (B) $(n=5)$ versus adult nonRFN (C) $(n=5)$; (A) $<$ (B), $p<0.01$ and (A) $>$ (C), $p<0.01$; (ii) unfractionated cord PMN (a) $(n=5)$ versus cord RFN (b) $(n=$ 5) versus cord non-RFN (c) $(n=5)$; (a) $<$ (b), $p<0.01$ and (a) versus (c), NS; (iii) (A) > (a), $p<0.01$; (iv) (B) $>$ (b), $p<0.05$ and $(C)$ versus (c), NS. Similarly, differences in adherence were as follows: (i) (A) $(n=13)$ versus $(B)(n$ $=4)$, NS and (A) > (C) $(n=4), p<0.01$; (ii) (a) $(n=4)$ versus (b) $(n=4)$, NS and (a) $>$ (c) $(n=4), p<0.01$; (iii) (A) $>$ (a), $p<0.05$; (iv) (B) versus (b), NS and (C) versus (c), NS. These results suggest that differences in chemotaxis and adherence between cord and adult PMN may relate in part to differences of PMN subpopulations. (Pediatr Res 25:6-10, 1989)
\end{abstract}

\section{Abbreviations}

RFN, rosette-forming neutrophils non-RFN, nonrosette-forming neutrophils PMN, polymorphonuclear neutrophils EAP, endotoxin-activated plasma LPS, lipopolysaccharide $\mathrm{RBC}$, red blood cells EA, erythrocytes sensitized with antibody

Decreased PMN chemotaxis and adherence in neonates are an important cause for increased susceptibility of neonates to overwhelming bacterial infections. Although the abnormalities of both the cellular and humoral immune systems have been demonstrated $(3,5-9)$, the mechanism of decreased chemotaxis and adherence is not well understood. The cinevideo assay (10) and

Received March 29, 1988; accepted August 24, 1988.

Correspondence and reprint requests to Kiyokazu Masuda, Department of Pediatrics, Kansai Medical University, Fumizonocho 1, Moriguchi, Osaka 570, Japan.

Supported by Grants-in-Aid for Scientific Research, Project 61570477 , 61770717, Grant-in-Aid of the Japan Medical Association and Mami Mizutani Foundation.
Zigmond's method (11) prove that from the point of chemotaxis neutrophils have at least slowly and fast moving cells. In other words it is assumed that neutrophils that have so far been considered to be homogeneous cells have two heterogeneous subpopulations (12-14). Wong et al. (15) first investigated the method to examine the Fc receptor, forming EA rosettes which were assayed with rabbit antisheep $\mathrm{RBC}$ IgG.

Developing a modified method with rabbit antihuman RBC IgG, Klempner et al. (16) separated neutrophils into RFN and non-RFN populations and found that the RFN were functionally superior to the non-RFN. Using this method, we studied Fc receptor expression in PMN chemotaxis and adherence in neonates and adults. We noted a significantly lower Fc receptor expression and lower chemotactic and adherent response in neonates than in adults. Our results suggest that decreased PMN chemotaxis and adherence in neonates may relate in part to differences of PMN subpopulations.

\section{MATERIALS AND METHODS}

Blood samples. Blood $(5-10 \mathrm{ml})$ was collected with $20 \mathrm{U} / \mathrm{ml}$ of heparin from the placental end of the cut umbilical cords of 13 healthy neonates (seven males and six females, body wt 2700 $3500 \mathrm{~g}$, gestational age 38-41 wk, APGAR score 8-10) at normal delivery. They were in good health after the APGAR score had been obtained and were cared for in the Department of Obstetrics and Gynecology of Kansai Medical University Hospital. Informed consent was obtained from mothers. For control studies, $5-10 \mathrm{ml}$ of venous blood was obtained from 16 healthy adult donors.

Isolation of neutrophils. Neutrophils were isolated by FicollHypaque (Sigma Chemical Co., St. Louis, MO) density centrifugation followed by dextran sedimentation described by Böyum (17). Residual erythrocytes were hypotonically lysed with distilled water. Finally, cells were suspended in $2 \mathrm{ml}$ of RPMI 1640 (pH 7.30, GIBCO, Santa Clara, CA) at $1 \times 10^{7}$ cells $/ \mathrm{ml}$. The viability was more than $96 \%$, as judged by trypan blue exclusion, and the purity was more than $97 \%$.

Preparation of EAP. Escherichia coli LPS (Sigma) was placed into a $40 \mu \mathrm{g} / 20 \mu \mathrm{l} /$ tube and stored at $-80^{\circ} \mathrm{C}$ until needed. In the assay, $0.4 \mathrm{ml}$ of plasma from cord or adult blood was added to a tube containing LPS and it was incubated for $30 \mathrm{~min}$ at $37^{\circ} \mathrm{C}$. The plasma was then inactivated at $56^{\circ} \mathrm{C}$ in a water bath for 30 min. In addition, $1.6 \mathrm{ml}$ of McCoy's $5 \mathrm{~A}$ media (GIBCO) with $10 \%$ FCS (Sigma) was added to make a final dilution of LPS of $20 \mu \mathrm{g} / \mathrm{ml}$.

Preparation of $E A$. Erythrocytes were obtained from healthy adult donors (blood type $\mathrm{O}$ ) and stored in Alsever's solution in the cold. RBC were washed three times in PBS $(0.163 \mathrm{M}, \mathrm{pH}$ 7.30) and adjusted to contain $1 \times 10^{9} \mathrm{RBC} / \mathrm{ml}$ in RPMI 1640 . Cells were counted by a microcell counter CC-130 A (Toa Medical Electronics Corporation, Japan). Rabbit antihuman 
RBC IgG was obtained from Cappel Laboratories (Cochranville, PA) (Lot 21403). The agglutinating titer of this IgG preparation as determined in microtiter plates was 1:400. A $2 \mathrm{ml} \mathrm{RBC}$ suspension $\left(1 \times 10^{9} / \mathrm{ml}\right.$ in RPMI 1640$)$ and IgG preparation diluted in RPMI 1640 were mixed and incubated at $37^{\circ} \mathrm{C}$ for 30 min. After incubation, EA were washed twice in cold RPMI 1640 and adjusted to contain $4 \times 10^{8} \mathrm{RBC} / \mathrm{ml}$ in fresh RPMI 1640.

Preparation of EA rosettes. A 2-ml neutrophil suspension, 0.5 $\mathrm{ml}$ of salt-poor human albumin $(25 \%)$ (Alpha Therapeutic Corporation, Los Angeles, CA) and $2.5 \mathrm{ml}$ of EA were placed into a siliconized 10-ml glass tube. The cell suspension was centrifuged at $60 \times \mathrm{g}$ at $20^{\circ} \mathrm{C}$ for $10 \mathrm{~min}$. The supernatant was discarded and the pellet was incubated for $15 \mathrm{~min}$ at $20^{\circ} \mathrm{C}$ and gently resuspended in RPMI 1640. A small aliquot was removed for counting the percentage of RFN, i.e. neutrophils with three or more attached RBC. At least 250 cells were counted to determine the percentage of RFN.

Separation of $R F N$ and non-RFN. After resuspension of neutrophil-EA, a 4-ml aliquot of the suspension was placed over Ficoll-Conray discontinuous density gradient in a siliconized 15$\mathrm{ml}$ glass tube. Gradients were prepared as previously described by Wong et al. (15). Solution I contained $11.2 \mathrm{~g}$ Ficoll (mol wt 400,000 , Sigma) and $20 \mathrm{ml}$ of Conray (meglumine iothalamate $600 \mathrm{mg} / \mathrm{ml}$, Mallinckrodt Inc., St. Louis, MO) in $100 \mathrm{ml}$ distilled water. Solution II contained $7.2 \mathrm{~g}$ Ficoll and $20 \mathrm{ml}$ of Conray in $100 \mathrm{ml}$ distilled water. A total of $3 \mathrm{ml}$ of solution II was layered over $3 \mathrm{ml}$ of solution I. Cell suspensions were then layered over solution II and centrifuged at $1500 \times \mathrm{g}$ for $25 \mathrm{~min}$ at $4^{\circ} \mathrm{C}$. The non-RFN were at the interface between the two Ficoll-Conray solutions, and the more dense RFN were in the cell pellet. Each fraction was collected by aspiration and washed twice in RPMI 1640. EA were removed from RFN by hypotonic lysis with distilled water.

Chemotaxis assay. Neutrophil chemotactic assay was determined using the acrylic blind well chemotaxis chamber (Neuro Probe, Inc., Cabin John, MD). The assay procedure was the modified Boyden method (1). Each cell suspension was adjusted to contain $1 \times 10^{6} / \mathrm{ml}$ in McCoy's $5 \mathrm{~A}$ media with $10 \% \mathrm{FCS}$. The upper compartment of a chemotaxis chamber received 200 $\mu \mathrm{l}$ of the suspension, and $200 \mu \mathrm{l}$ of EAP as a chemoattractant or $200 \mu \mathrm{l}$ of McCoy's 5A media with $10 \%$ FCS as a negative control were placed into the lower compartment. The compartments were separated by a $3-\mu \mathrm{m}$ pore-sized polycarbonate filter with a 13-mm diameter (Nuclepore Co., Pleasanton, CA). After incubation for $45 \mathrm{~min}$ at $37^{\circ} \mathrm{C}$, saline was added by a Pasteur pipette into each of the upper compartments in triplicate chambers, and the fluid was aspirated. The filters were removed with a forceps and placed upside down on a glass slide and rinsed in consecutive ethanol solutions $(80,70,50 \%)$ and stained with Wright's stain and hematoxylin. Each filter was scanned on high power field $(\times 1000)$, and neutrophils that had migrated completely through the filter in 10 representative fields were counted. Chemotaxis was determined by the means of triplicate samples.

Adherence assay. Glass beads, 4-mm diameter (Sohgo-Rikagaku Glass Co., Japan), were prepared by washing in distilled water and drying overnight at $37^{\circ} \mathrm{C}$. Thirty-five beads were placed into each $5-\mathrm{ml}$ plastic syringe, and the tip was sealed with a parafilm (American Can Co., CT). Then, $1 \mathrm{ml}$ of ${ }^{51} \mathrm{Cr}$-labeled neutrophils (4) at a concentration of $1 \times 10^{6}$ cells $/ \mathrm{ml}$ and $100 \mu \mathrm{l}$ of EAP or $100 \mu \mathrm{l}$ McCoy's 5A media with $10 \%$ FCS as a negative control was layered over the beads, and the syringe was closed with a piston, then incubated with rotation at $20 \mathrm{rpm}$ at $37^{\circ} \mathrm{C}$ for $60 \mathrm{~min}$. After incubation, the piston was removed, and $2 \mathrm{ml}$ of McCoy's media were added to each syringe, and the parafilm on each outlet was perforated by a heated needle. The elution fluid was collected into a $12 \times 75 \mathrm{~mm}$ polystylen tube (Falcon Labware, Becton, Dickinson \& Co., Oxnard, CA), and beads were collected into another tube. The sample was triplicated and counted in a gamma counter (Packard Instrument Co., Downers
Grove, IL) to determine the relative percentage of adherence of neutrophils, calculated as follows:

$$
\begin{array}{r}
\frac{\text { count of the beads }(\mathrm{cpm})}{\text { count of the beads }+ \text { elution fluid }(\mathrm{cpm})} \times 100 \\
=\text { percentage of adherence }
\end{array}
$$

Under the same conditions, the adherence value of stimulated PMN of healthy adults by EAP was $67.7 \pm 5.8 \%$. Therefore, the reproducibility of this adherence assay was less than $6 \%$.

Statistical analysis. Statistical analysis was carried out using the Student's $t$ test for comparison of means for paired samples and analysis of variance in conjunction with Scheffes test for comparisons of multiple means. A $p$ value of $<0.05$ was considered significant in all cases. Data were reported as means \pm SD.

\section{RESULTS}

Determination of optimal concentration of rabbit antihuman $R B C \operatorname{Ig} G$ and $E A /$ neutrophil ratio for rosette formation. When EA were prepared with dilutions of rabbit antihuman RBC IgG between 1:400 and 1:1200, the percentage of RFN increased with dilutions of antibody and reached the maximum at 50\% (1:800) of agglutinating titer. When the EA/neutrophil ratio was in a range of $10-100$ at this concentration of antibody, the percentage of RFN peaked at $50 \mathrm{EA} /$ neutrophil. Consequently, the combination of diluted antibody at 1:800 and $50 \mathrm{EA} /$ neutrophil was considered to be optimal in this study.

Percentage of RFN. The percentage of RFN of cord and adult blood samples is compared in Figure 1. The cord blood values ranged from $23-52 \%$ with a mean of $35 \%$. The adults ranged from $50-70 \%$ with a mean of $60 \%$. The cord blood values were significantly lower than the adult values $(p<0.01$, Student's $t$ test) when the means were compared.

RFN were examined to determine whether there is a difference in the number of attached RBC between segmented and band neutrophils. For this purpose, small aliquots of the suspension and acridine orange (Daiichi Pure Chemicals Co., Japan) diluted

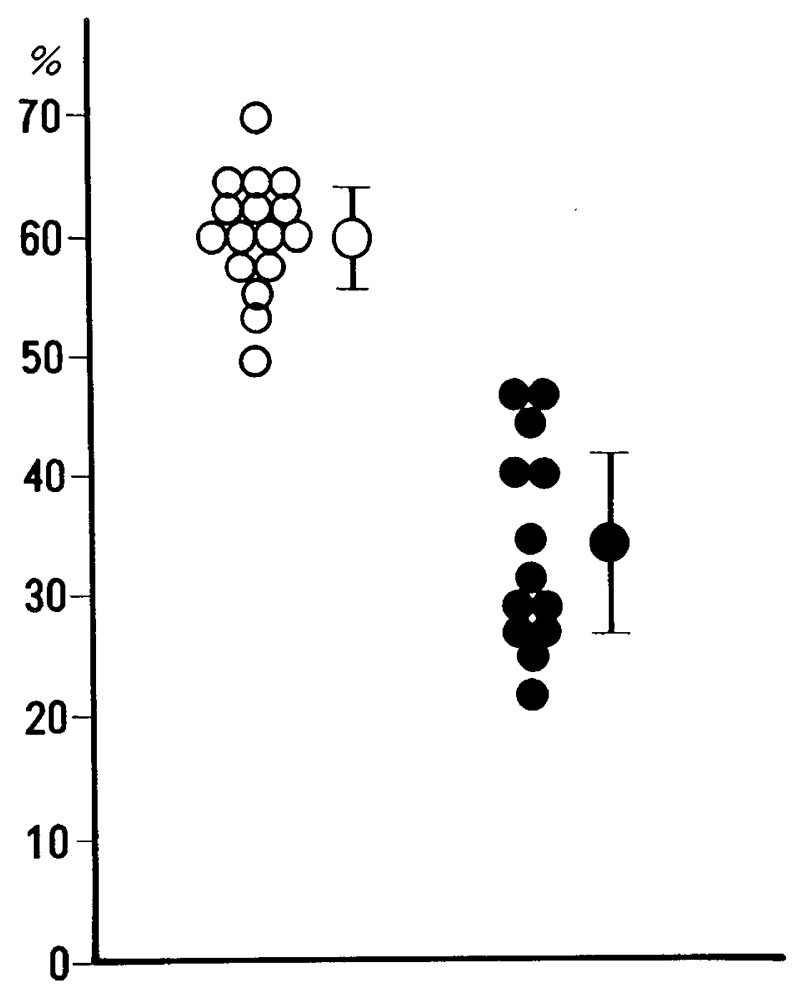

Fig. 1. Difference in rosette formation capacity between $\operatorname{cord}(\bullet, n=$ 13) and adult $(O, n=16) \mathrm{PMN}$. Results are expressed as mean $\pm 1 \mathrm{SD}$. Significant difference $(p<0.01)$ was noted between the two groups. 
1:10,000 in PBS were gently mixed on a glass slide and covered with a glass coverslip. Then the slide was scanned on a fluorescent microscope with UV illumination filtered to $520 \mathrm{~nm}$, and at least $100 \mathrm{RFN}$ were counted to determine the number of attached $\mathrm{RBC}$ (results are shown in Table 1). Statistical differences were noted as indicated in the footnote to Table 1.

Chemotaxis. As shown in Figure 2, differences in chemotaxis in PMN subpopulations between cord and adult PMN were as follows: (i) unfractionated adult PMN (A) (32 \pm 2 migrated cells), adult RFN (B) (52 \pm 4 ), adult non-RFN (C) $(20 \pm 1)$, (ii) unfractionated cord PMN (a) $(23 \pm 2)$, cord RFN (b) $(43 \pm 2)$, cord non-RFN (c) $(19 \pm 1)$.

Adherence. As shown in Figure 3, differences in adherence of PMN subpopulations were as follows: (i) unfractionated adult PMN (A) $(68.3 \pm 6.6 \%)$, adult RFN (B) $(69.5 \pm 9.7 \%)$, adult non-RFN (C) (24.4 $\pm 0.7 \%$ ), (ii) unfractionated cord PMN (a) $(54.9 \pm 9.8 \%)$, cord RFN (b) $(53.8 \pm 3.2 \%)$, cord non-RFN (c) $(12.8 \pm 6.8 \%)$.

Table 1. Differences in rosette formation capacity of segmented and band neutrophils between cord and adult PMN

\begin{tabular}{|c|c|c|c|c|c|c|}
\hline \multicolumn{2}{|c|}{$\begin{array}{c}\text { Number of } \\
\text { attached RBCs }\end{array}$} & 3 & 4 & 5 & 6 & $7<$ \\
\hline \multirow{2}{*}{$\begin{array}{c}\text { Neut rophils } \\
\text { blood }\end{array}$} & Segmented & $\begin{array}{c}8 \pm 6^{*} \\
(\mathrm{~A})\end{array}$ & $\begin{array}{c}14 \pm 1 \\
(\mathrm{~B})\end{array}$ & $\begin{array}{c}13 \pm 2 \\
(\mathrm{C})\end{array}$ & $\begin{array}{c}13 \pm 4 \\
(\mathrm{D})\end{array}$ & $\begin{array}{c}32 \pm 1 \\
(\mathrm{E})\end{array}$ \\
\cline { 2 - 7 } & Band & $\begin{array}{c}2 \pm 1 \\
(\mathrm{~F})\end{array}$ & $\begin{array}{c}4 \pm 1 \\
(\mathrm{G})\end{array}$ & $\begin{array}{c}5 \pm 1 \\
(\mathrm{H})\end{array}$ & $\begin{array}{c}5 \pm 1 \\
(\mathrm{II})\end{array}$ & $\begin{array}{c}6 \pm 1 \\
(\mathrm{~J})\end{array}$ \\
\hline \multirow{3}{*}{$\begin{array}{c}\text { Cord } \\
\text { blood }\end{array}$} & Segmented & $\begin{array}{c}19 \pm 2 \\
(\mathrm{a})\end{array}$ & $\begin{array}{c}21 \pm 4 \\
(\mathrm{~b})\end{array}$ & $\begin{array}{c}9 \pm 1 \\
(\mathrm{~d})\end{array}$ & $\begin{array}{c}6 \pm 2 \\
(\mathrm{~d})\end{array}$ & $\begin{array}{c}14 \pm 5 \\
(\mathrm{e})\end{array}$ \\
\cline { 2 - 7 } & Band & $\begin{array}{c}4 \pm 1 \\
(\mathrm{f})\end{array}$ & $\begin{array}{c}7 \pm 2 \\
(\mathrm{~g})\end{array}$ & $\begin{array}{c}5 \pm 3 \\
(\mathrm{~h})\end{array}$ & $\begin{array}{c}5 \pm 2 \\
(\mathrm{i})\end{array}$ & $\begin{array}{c}10 \pm 2 \\
(\mathrm{j})\end{array}$ \\
\hline
\end{tabular}

* Percent mean \pm 1 SD. $p<0.01$ : (E) $>$ (e); (D) $+(\mathrm{E})>(\mathrm{d})+(\mathrm{e}) . p<$ 0.02: (A) < (a); (A)+(B) < (a)+(b); (F) $+(\mathrm{G})<(\mathrm{f})+(\mathrm{g}) . p<0.05:(\mathrm{B})<$ (b); (C) $>$ (c); (D) $>$ (d); (F) < (f); (J) < (j); (I)+(J) < (i) +(j). N.S. (G) versus $(\mathrm{g}) ;(\mathrm{H})$ versus $(\mathrm{h}) ;(\mathrm{I})$ versus $(\mathrm{i})$.

\section{DISCUSSION}

The mechanism of decreased PMN chemotaxis and adherence in neonates is not well understood. Miller $(1,2)$ suggests that the cell is rigid and lacks the capability of deforming in response to chemotactic stimulation and that decreased PMN chemotaxis is a main cause of increased susceptibility of neonates to overwhelming bacterial infections. We reported previously that, using ${ }^{51} \mathrm{Cr}$-labeling assay (4), PMN chemotaxis and adherence in neonates were significantly decreased when compared to those of adults. Our present study further indicate that decreased PMN chemotaxis and adherence in neonates may relate in part to differences to PMN subpopulations, i.e. RFN and non-RFN representing $\mathrm{Fc}$ receptor expression.

The percentage of RFN was significantly lower in cord blood than in adult. By contrast, Pross et al. (18) reported that the average percentage of cord and adult RFN was identical. It is thought that the discrepancy may lie in the difference between sheep and human erythrocytes, i.e. probes necessary for rosette formation, and other technical procedures. In this respect, Whited et al. (19) noted that many kinds of cells which were rosette negative with the human erythrocyte formed rosettes with the sheep erythrocytes. Based on this observation, they considered that the human erythrocyte appeared to be a more sensitive probe for studying PMN subpopulations than the sheep erythrocyte and that the difference of rosette formation from probe cells was perhaps due to some characteristics of probe cells unrelated to their $\mathrm{Fc}$ receptor.

The present chemotactic assay showed that cord RFN were more chemotactic than unfractionated cord PMN and cord nonRFN, respectively. From these results, we also confirmed that neonatal neutrophils consist of two different populations and further concluded that the average percentages of cord and adult RFN are entirely different. Therefore, differences in rosetteforming capacity between cord and adult PMN using human erythrocytes may account for differences in chemotaxis so far observed between these two kinds of PMN. Furthermore, comparison of the rosette-forming capacity of segmented and band neutrophils between cord and adult PMN showed that the rosette-forming capacity of segmented neutrophils of cord PMN was significantly lower than that of adult PMN. This observation

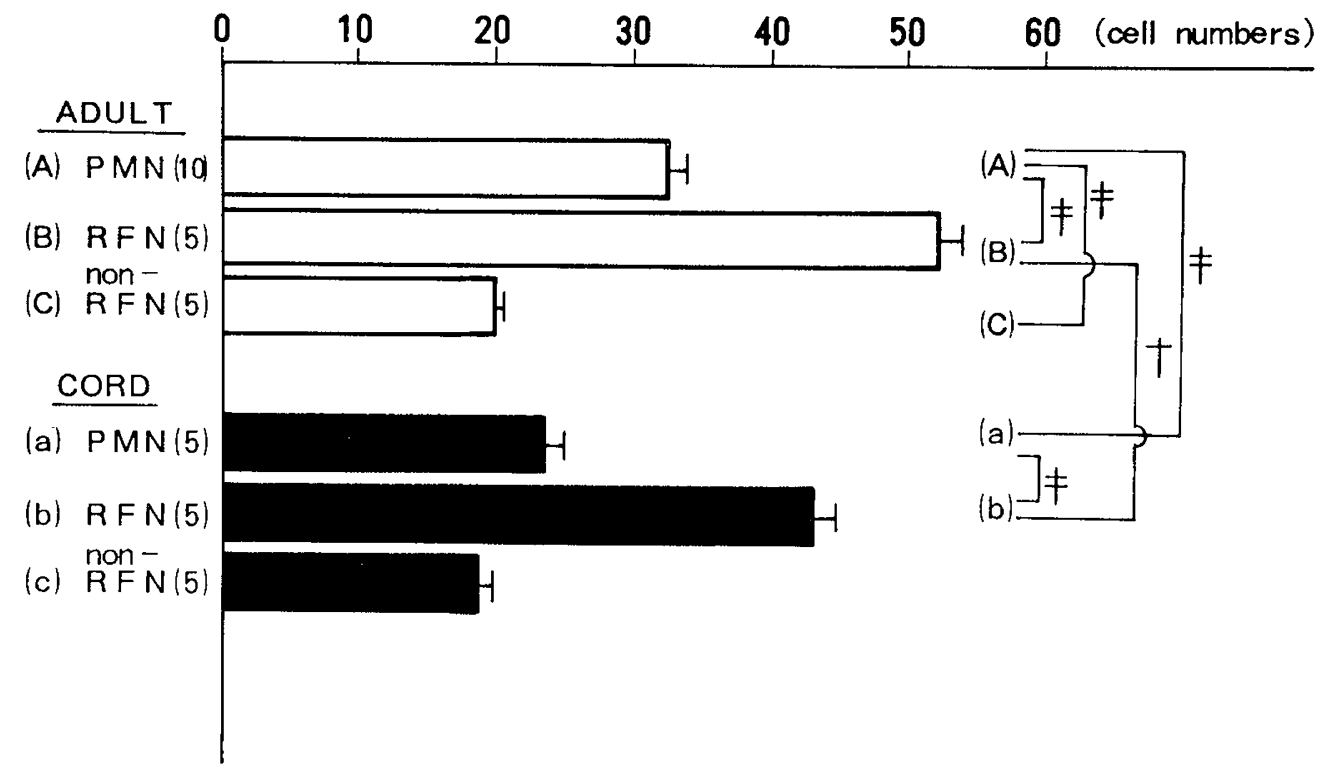

Fig. 2. Differences in chemotaxis of PMN subpopulations between cord and adult PMN after stimulation by their own EAP. Abscissa indicates the number of migrated cells $\pm 1 \mathrm{SD}$. Numbers in parentheses indicate numbers of specimens studied. $\dagger, p<0.05 ; \neq, p<0.01$. 


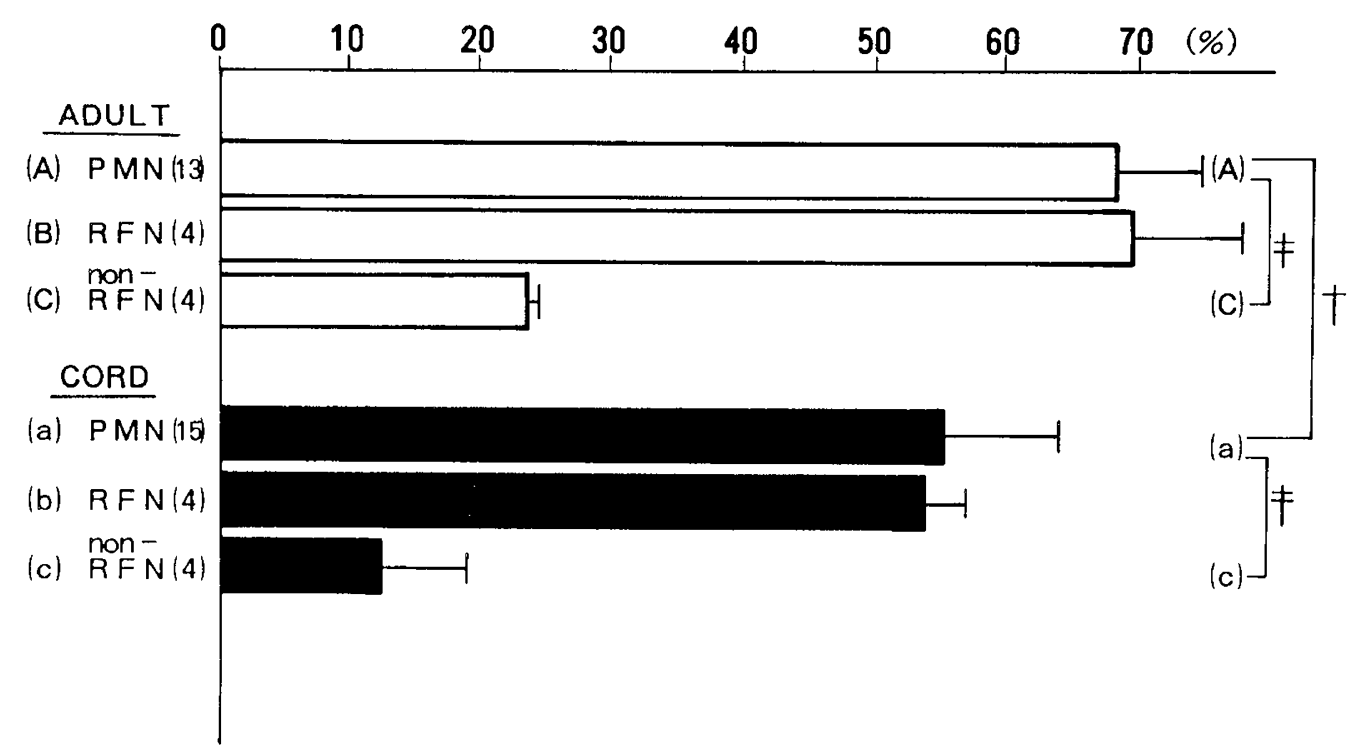

Fig. 3. Differences in adherence of PMN subpopulations between cord and adult PMN after stimulation by their own EAP. The abscissa indicates the percentage of adherence $\pm 1 \mathrm{SD}$. The numbers in parentheses indicate numbers of specimens studied. $\dagger, p<0.05 ; \ddagger, p<0.01$.

appears to reflect the low capacity of rosette formation of cord PMN. Boner et al. (12) demonstrated that the band form from both cord and adult PMN had a less mean migration than the segmented form. Based on this observation, they considered that an increase in chemotactic response during neutrophil maturation may partially contribute to the smaller total chemotactic response of cord PMN compared to adult PMN because cord PMN had more band forms (31\%) than adult PMN $(8 \%)$. This explanation may be plausible, but we would rather think that a decreased PMN chemotaxis is perhaps due in part to the significantly low capacity of rosette formation of segmented neutrophils which occupy the majority of PMN. In support of this speculation, Krause et al. (20) pointed out with a mouse MAb (31D8) that there was a greater percentage of immature PMN (bands and metamyelocytes) in neonates than in adults, yet immature PMN were equally distributed in the $31 \mathrm{D} 8$ bright (more motile cells) and dull (less motile cells) subpopulations. According to Lewis et al. (21), although the segmented and band neutrophils of adult PMN similarly reached optimal EA rosettes, segmented neutrophils were more chemotactic than band neutrophils. However, we could not delineate the relationship between rosette forming capacity and functional capacity of cord PMN.

In the first line of host defense mechanism, the role of PMN adherence is important not only in PMN to the vascular endothelium but also in preliminary anchoring of the cell for forward chemotaxis. There are few reports in regard to PMN adherence in neonates; furthermore, there is a discrepancy of results which appears to be due to the difference of methodologies. Krause and coworkers $(22,23)$ found that neutrophil adherence of neonates was decreased when compared with that of adults, whereas Rao et al. (24) reported that it was significantly increased. However, Fontan et al. (25) noted that PMN adherence was similar in both. Adherence assay with ${ }^{51} \mathrm{Cr}$ glass beads yielded similar results to those of Krause and coworkers $(22,23)$ and showed reproducibility of less than $6 \%$. With this sufficiently sensitive method, significant differences in adherence of PMN subpopulations between cord and adult PMN were noted between RFN and nonRFN. This observation suggests that differences of adherence are due at least to differences between RFN and non-RFN, as was observed in PMN chemotaxis.

In summary, our present study has shown that neonatal neutrophils have two heterogeneous subpopulations, indicating that PMN chemotaxis and adherence are characterized by the differ- ence of rosette-forming capacity. Although the origin of PMN subpopulations is still unknown as Gallin (13) pointed out, it seems likely that differences of PMN subpopulations may be responsible in part for the cause of decreased PMN chemotaxis and adherence in neonates. Further examination into the heterogeneity of Fc receptor expression appears to provide more information about PMN defects in neonates.

Acknowledgments. The authors are grateful to the staff of the Department of Obstetrics and Gynecology of the Kansai Medical University for supplying the cord blood samples.

\section{REFERENCES}

1. Miller ME 1971 Chemotactic function in the human neonate: humoral and cellular aspects. Pediatr Res 5:487-492

2. Miller ME 1975 Developmental maturation of human neutrophil motility and its relationship to membrane deformability. In: Bellanti JA, Dayton DH (eds) The Phagocytic Cell in Host Resistance. Raven Press, New York

3. Klein RB, Fischer TJ, Gard SE, Biberstein M, Rich KC, Stiehm ER 1977 Decreased mononuclear and polymorphonuclear chemotaxis in human newborns, infants and young children. Pediatrics 60:467-472

4. Kinoshita Y, Masuda K, Ono A, Kojima T, Matsuzaki S, Iwase S, Kobayashi Y 1987 Evaluation of neutrophil functions in the early neonatal period with Cr-labeling method. Acta Neonat Jpn 23:501-505

5. Pahwa SG, Pahwa R, Grimes E, Smithwick E 1977 Cellular and humoral components of monocytes and neutrophil chemotaxis in cord blood. Pediatr Res 11:677-680

6. Nunoi H, Endo F, Chikazawa S, Namikawa T, Matsuda I 1983 Chemotactic receptor of cord blood granulocytes to the synthesized chemotactic peptide $n$-formyl-methionyl-leucyl-phenylamine. Pediatr Res 17:57-60

7. Fontan G, Lorente F, Rodriguez MCG, Ojeda JA 1981 In vitro human neutrophil movement in umbilical cord. Clin Immunol Immunopathol 20:224-230

8. Tono-oka T, Nakayama M, Uehara H, Matsumoto S 1979 Characteristics of impaired chemotactic function in cord blood leukocytes. Pediatr Res 13:148151

9. Hill HR 1987 Biochemical, structural, and functional abnormalities of polymorphonuclear leukocytes in neonate. Pediatr Res 22:375-382

10. Howard TH 1982 Quantification of the locomotive behavior of polymorphonuclear leukocytes in clot preparations. Blood 59:946-951

11. Zigmond SH, Sullivan SJ 1979 Sensory adaptation of chemotactic peptides. J Cell Biol 82:517-527

12. Boner A, Zeligs BJ, Bellanti JA 1982 Chemotactic responses of various differentiational stages of neutrophils from human cord and adult blood. Infect Immun 35:921-928

13. Gallin JI 1984 Human neutrophil heterogeneity exists, but is it meaningful? Blood 63:977-983

14. Klempner MS 1980 Neutrophil heterogeneity as a possible basis for chemotaxis. Ann Intern Med 92:529

15. Wong $\mathrm{L}$, Wilson JD 1975 The identification of $\mathrm{Fc}$ and $\mathrm{C} 3$ receptors on human 
neutrophils. J Immunol Methods 7:69-76

16. Klempner MS, Gallin JI 1978 Separation and functional characterization of human neutrophil subpopulations. Blood 51:659-669

17. Böyum A 1968 Isolation of mononuclear cells and granulocytes from human blood. Scand J Clin Lab Invest 21:(suppl 97)77-89

18. Pross SH, Hallock JA, Armstrong R, Fishel CW 1977 Complement and FC receptors on cord blood and adult neutrophils. Pediatr Res 11:135-137

19. Whited SC, Santaella M, Frank MM, Gaither T, Gallin JI 1981 Binding of immunoglobulin-and complement-coated erythrocytes to human neutrophil subpopulations. Inflammation 2:103-1 14

20. Krause PJ, Malech HL, Kristie J, Kosciol CM, Herson VC, Eisenfeld L, Pastuszak WT, Kraus A, Seligmann B 1986 Polymorphonuclear leukocyte heterogeneity in neonates and adults. Blood 68:200-204

21. Lewis G, Roger LF 1987 Functional differentiation of normal human neutrophils. Blood 69:937-944

22. Krause PJ, Maclevago EG, Scroggs M 1982 Abnormalities of neutrophil adherence in newborns. Pediatrics 69:184-187

23. Krause PJ, Herson VC, Boutin-Lebowitz J, Eisenfeld L, Block C, LoBello T, Maserazo EG 1986 Polymorphonuclear leukocyte adherence and chemotaxis in stressed and healthy neonates. Pediatr Res 20:296-300

24. Rao S, Olesinski R, Dohsi U, Vidyasagar D 1981 Granulocyte adherence in newborn infants. J Pediatr 97:622-624

25. Fontan G, Lorente F, Rodriguez MCG, Ojeda JA 1979 Granurocyte adherence in umbilical cord blood. J Pediatr 94:969-970 